\title{
Explore the Social Life of Male Migrant Youth Work in Informal Sector Khartoum State
}

\author{
Amna Ahmed Abdallah Elsheikh1', Shadia Daoud ${ }^{2}$, Fatima Ezeldeen' \\ ${ }^{1}$ Sudan University of Science and Technology, Agricultural Studies, Agricultural Extension and Rural Development Department, \\ Khartoum, Sudan \\ ${ }^{2}$ Ahfad University for Women, Agricultural Extension and Rural Development Department, Khartoum, Sudan \\ Email:amnaahmed1981@yahoo.com,abdelrahimshadia@gmail.com, fatimaezeldin@sust.edu
}

How to cite this paper: Elsheikh, A.A.A., Daoud, S. and Ezeldeen, F. (2020) Explore the Social Life of Male Migrant Youth Work in Informal Sector Khartoum State. Open Access Library Journal, 7: e6599. https://doi.org/10.4236/oalib.1106599

Received: July 9, 2020

Accepted: August 22, 2020

Published: August 25, 2020

Copyright $\odot 2020$ by author(s) and Open Access Library Inc.

This work is licensed under the Creative Commons Attribution International License (CC BY 4.0).

http://creativecommons.org/licenses/by/4.0/

\begin{abstract}
The study was conducted to investigate the social life of migrant's youth who work in informal sectors. The study is explanatory and descriptive in nature explained the social life of 300 migrants' youth selected form three markets of Khartoum State. Qualitative and quantitative techniques utilized to collect data. The study findings show $88 \%$ of youth migrated searching for a job for a better life. The socio-economic situation characterized by vulnerability, poverty and low skill to get the job outside of the informal sector. 81.9\% of youth lived in small rent house together with group of migrant youth. The majority of youth could not integrate themselves into host community of Khartoum State. It is found that the migrants' youth limited their friendship to their migrants' counterparts who work in the markets. Despite the difficulties of the life in Khartoum but still migrants youth do not have planned to go back to their place of origin, because of the availability of work. The study concluded that migrants youth have no time to integrate with people outside their own community, finally the study concluded that the isolated life style of the migrants youth limited their contact with host community. The study recommended the need for advocacy programs by government and civil societies to raise awareness of migrant youths for social integration.
\end{abstract}

\section{Subject Areas}

Anthropology, Sociology

\section{Keywords}

Social Life of Migrant's Youth, Work in Informal Sectors, and Integrate with People outside Their Own Community 


\section{Background}

By 2030 it is estimated that all developing regions will have more people living in urban areas than rural areas, with virtually all the world's population growth concentrated in urban areas over the next 30 years. Rural urban migration is main cause of growing of urbanization in developing countries. Rural urban migration recently has new pattern that majority of migrants are youth. Rural migrants living in urban areas are often young people. Young people tend to make up about half the total African rural to urban migration, with many more migrants being very young indeed. Most urban youth, and particularly youth migrants, live in unplanned settlement areas, often squalid conditions with no social services of amenities. Across Africa, the majority are no longer in school and are unable to get jobs.

Sudan witnessed severe civil war since the 1980s, the conflict and poverty compelled thousands of people to flee their homeland to other areas in and/or outside the country in search of safety and/better living condition. Considerable numbers of those migrants were targeted Khartoum State and live in the periphery of Khartoum City and find their work in informal sector. Many studies conducted investigated the work of youth migrant in formal sectors but few studies conducted to investigate the new social life of migrants youth in urban setting, So this study attempts to explore the social life of migrants youth challenges, integration with host community and their future perspective.

\section{Specific objectives:}

- To describe the Profile of migrant youth;

- To Identify Reasons for Migration;

- To Identify Housing and living condition;

- Explore the migrant youth Contact with their home in rural areas;

- To study the Integration of migrant youth with people in Khartoum and development of Friendship;

- To examine the opinion of migrant youth on the livelihood in Khartoum State;

- To explore the future plan of Migrant youth.

\section{Methodology}

The study is explanatory and descriptive in nature which provides numerical description of some part of the population and explains events using comprehensive questionnaire directed to migrant youth work in three local markets Khartoum States. 300 migrants' youth who work in three markets of Khartoum State were purposively selected.The data obtained from this study was explored on the basis of questions and specific objectives by use of both quantitative and qualitative techniques. The data was structured to answer set objectives in the study. Data was then analyzed using both descriptive. And content analysis.

\section{Results}

\subsection{Profile of Migrant Youth}

The age of migrants youth interviewed within the age defined by the united na- 
tion 15 - 25 years old. $49 \%$ percent of them were between the 15 - 18 years old, while $51 \%$ of them between 19 - 25. Literacy was low among migrants youth about $51 \%$ of migrant youth had brothers and sisters out of the education. Father were the head of the household of most of the sample of migrant youth (see Table 1).

Table 1. Frequency Distribution of migrants according to their characteristics.

\begin{tabular}{|c|c|c|}
\hline Characteristics & Frequency & Percent \\
\hline \multicolumn{3}{|l|}{ Age } \\
\hline $15-18$ & 147 & 49.0 \\
\hline $19-25$ & 153 & 51.0 \\
\hline Total & 300 & 100.0 \\
\hline \multicolumn{3}{|l|}{ Education levels } \\
\hline Uneducated & 3 & 1.0 \\
\hline Primary & 115 & 38.5 \\
\hline High secondary & 158 & 52.8 \\
\hline University degree & 23 & 7.7 \\
\hline Total & 299 & 100.0 \\
\hline \multicolumn{3}{|l|}{ Brothers in school } \\
\hline Yes & 145 & 48.3 \\
\hline No & 155 & 51.7 \\
\hline Total & 300 & 100.0 \\
\hline \multicolumn{3}{|l|}{ Head of the household } \\
\hline No one & 2 & .7 \\
\hline Father & 208 & 70.3 \\
\hline Brother & 75 & 25.3 \\
\hline Other relatives & 10 & 3.4 \\
\hline Total & 296 & 100.0 \\
\hline \multicolumn{3}{|l|}{ Type of house hold job } \\
\hline Without job & 9 & 3.2 \\
\hline Business owners & 118 & 41.7 \\
\hline Farmer & 73 & 25.8 \\
\hline Herder & 10 & 3.5 \\
\hline Tailor & 3 & 1.1 \\
\hline Seller in small shops & 31 & 11.0 \\
\hline Labor & 29 & 10.2 \\
\hline Driver & 7 & 2.5 \\
\hline Employer & 3 & 1.1 \\
\hline Total & 283 & 100.0 \\
\hline
\end{tabular}

Source field work 2018. 


\subsection{Reasons for Migration}

The majority $88 \%$ of the migrants' youth migrated searching for a job for a better life, in addition to poverty of their families and war (see Table 2).

\subsection{The time of settlement in Khartoum}

Some of the migrants were new arrival 18.7\% while 69.6 lived in Khartoum for 3 to 6 years. Very few were more than 9 years (see Table 3 ).

\section{Housing}

Most of migrants youth $81.9 \%$ rent small houses with migrants friends. Others about $13.8 \%$ live with their relatives who settled before as a family, uncle or cousins. Very few $4.4 \%$ live with their family those who migrated with their family (see Table 4).

\section{Contact with place of origin}

Migrants youth kept good contact with their place of origin that $92 \%$ visit their area continuously specially during festivals or family's commitments (see Table 5).

Table 2. Frequency distribution of respondents according to migration reasons.

\begin{tabular}{ccc}
\hline Migration Reasons & Frequency & Percent \\
\hline Searching for a job & 264 & 88.0 \\
Poverty of the family & 27 & 9.0 \\
War and conflicts & 3 & 1.0 \\
Education & 6 & 2.0 \\
Total & 300 & 100.0 \\
\hline
\end{tabular}

Source field work 2018.

Table 3. Frequency distribution of respondents according to the time of settlement in Khartoum State.

\begin{tabular}{ccc}
\hline Time of settlement & Frequency & Percent \\
\hline Less than 2 years & 56 & 18.7 \\
3 - 6 years & 208 & 69.6 \\
6 - 9 years & 26 & 8.7 \\
More than 9 years & 9 & 3.0 \\
Total & 299 & 100.0 \\
\hline
\end{tabular}

Table 4. Frequency distribution of respondents according to with whom they live.

\begin{tabular}{ccc}
\hline Live with & Frequency & Percent \\
\hline Rent with friends & 244 & 81.9 \\
Family & 13 & 4.4 \\
relatives & 41 & 13.8 \\
Total & 298 & 100.0 \\
\hline
\end{tabular}




\subsection{Social Integration with People in Khartoum}

$61.4 \%$ of migrant youth could not socially integrate with people in Khartoum State (see Figure 1). The youth gave different reason of this lack of social integration. Most of migrants youth returned it to the difference of tradition also others argue that they don't knows them because of the life style of them (see Table 6).

As said on group discussion we have different traditions and values, other said our time is different we are busy working all the all the time.

Three said we lived in isolated area with our friends and relatives.

One of youth said we as migrants youth spend our time together because we have common interest, Some of them said there are no activities going on to encourage us integrate with other people (see Figure 1).

\subsection{Development of Friendship}

$85 \%$ of the sample developed friendship with people in Khartoum State (see Table 7).

Table 5. Frequency distribution of respondents according to visit their area continuously.

\begin{tabular}{ccc}
\hline Visit the village & Frequency & Percent \\
\hline Yes & 271 & 91.9 \\
No & 24 & 8.1 \\
Total & 295 & 100.0 \\
\hline
\end{tabular}

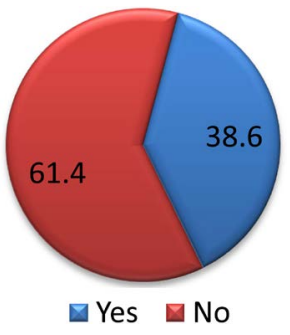

Figure 1. Integration with Khartoum Communities (host community).

Table 6. Frequency distribution of respondents according to why don't join Khartoum State community.

\begin{tabular}{ccc}
\hline Because of & Frequency & Percent \\
\hline Different traditions and values & 38 & 12.7 \\
We don't knows them & 73 & 24.3 \\
No common interest & 29 & 9.7 \\
We don't have time & 105 & 35.0 \\
No common activities & 53 & 17.7 \\
They don't want to join us & 2 & 0.6 \\
Total & 300 & 100.0
\end{tabular}


They said in group discussion we had fiends form the migrant youths who worked with us in the markets and came from different States.

Youth opinion on their livelihood in Khartoum:

The $55.7 \%$ of migrant youth prefer their livelihood in their area than Khartoum State while other 44.3 found easy to live in Khartoum (see Figure 2 and Table 8).

Migrant youth states in group discussion, "The life here is very difficult the availability of work encouraged us to continue living on Khartoum, Other said it's easy for us to live in Khartoum".

\subsection{Future Plan}

$88 \%$ of the migrant youth did not plan to go back to their area. See table some of them planed to travel and work outside Sudan (see Table 9 and Figure 3).

Table 7. Frequency distribution of respondents according to development of friendship.

\begin{tabular}{ccc}
\hline Friendship & Frequency & Percent \\
\hline Yes & 254 & 85.2 \\
No & 44 & 14.8 \\
Total & 298 & 100.0 \\
\hline
\end{tabular}

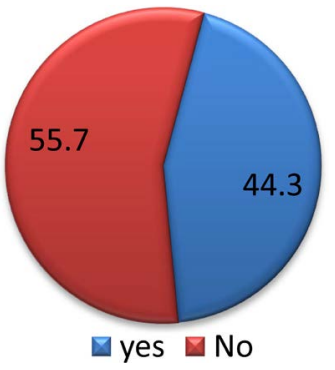

Figure 2. Frequency distribution of respondents according to their opinion on livelihood in Khartoum State.

Table 8. Frequency distribution of respondents according to their opinion on livelihood in Khartoum State.

\begin{tabular}{ccc}
\hline The easier to live in & Frequency & Percent \\
\hline Yes & 132 & 44.3 \\
No & 166 & 55.7 \\
Total & 298 & 100.0 \\
\hline
\end{tabular}

Table 9. Frequency distribution of respondents according to the future plans.

\begin{tabular}{ccc}
\hline My future plans to & Frequency & Percent \\
\hline Go back to my area & 263 & 88.3 \\
Settle in Khartoum State & 35 & 11.7 \\
Total & 298 & 100.0 \\
\hline
\end{tabular}




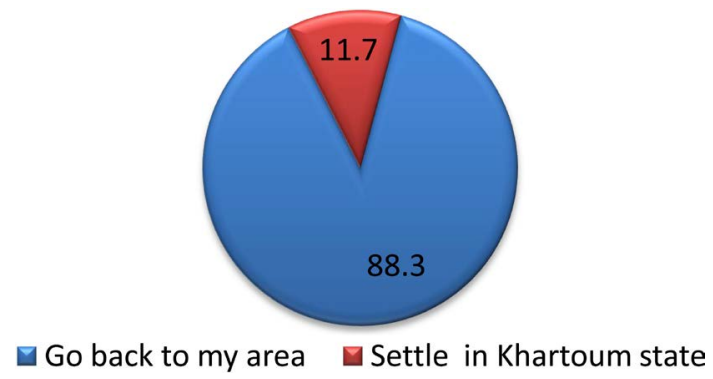

Figure 3. The Future plan.

\section{Discussion}

\subsection{Socio Demographic Characteristics of Migrant Youth}

The study found the young age of migrants youth some of them on the age group 15 - 18. And other on the age $19-25$ this goes with definition of the youth of UN. A third of total migrants from developing countries are aged 12 to 24 . Sudan has a very young population More than a third of all migrants worldwide are under the age of 29.

Two thirds of Sudanese are under the age of 34 . Over $20 \%$ of young people are unemployed. Youth migration data in Sudan indicated approximately one-fourth of all migrants are less than 18 years old, and that after age 12, the likelihood of migrating separately from parents begins to increase, with steepest increases between ages 15 and 17 (Yaqub, 2009) [1]. A quarter of youth, living in urban areas and half of those living in rural areas are poor. The result indicated low literacy rate of migrant youth as majority of them could not continue their education for socio economic reasons (poverty). The study indicates high education dropped out among the brothers and sisters of migrant youth, It is found that rural areas in Sudan lack education services. Rural youth are often found in unpaid family work, especially in agriculture, or employed as own-account, wage casual and seasonal workers in the informal economy, where they earn low wages, have limited job security and insufficient access to social protection.

\subsection{Reasons for Migration}

The decision of whether to migrate or not is one of many important decisions that young men and women make throughout the developing world. The results indicated majority of youth migrated searching of the jobs as majority before migration were unemployed. General trends Opportunities are often tied to current location, and many young s migrate to work or attend school, leaving their parents and natal homes behind.

The study indicated migration was livelihood strategies available to rural youth. Same results found by Youth migrated to, facilitate access to goods and services, or invest in income-generating activities. Unavailability work of areas where the youth migrated from was reason moved them to urban sector. According to ILO Unemployment rates for youth are almost three times higher than adults ones in all regions of the world, ranging from nearly two times in Sub-Saharan Africa 
has provided arguments explaining work in the agricultural sector suffers from a negative perception i.e. it is often associated with low returns, drudgery and demanding work but at the same time low social status.

\subsection{The Time of Settlement in Khartoum and with Whom They Live}

Most of youth did not live with their families they rent a house together with as group of youth from different areas, the number of year youth stay in Khartoum ranged between one year and up to ten year. This indicates the continues process of youth migration.

\subsection{Integration of Youth with Host Community in Khartoum State}

The finding indicates the lack of integration of the youth with Khartoum State community because they did not have time and their livelihood style isolated them from community Some literatures indicated youth commonly face social exclusion, disruption of family, and absence of social protection, Considerable numbers of those migrants in Khartoum State live in the periphery of Khartoum City (Bello, 2008) [2]. Rural youth have good social interaction with their counterparts from their areas and work together in the informal sector, indicated the social capita was high among rural migrant groups used it as strategy to limit their poverty and vulnerabilities.

\subsection{Youth Opinion on Their Livelihood in Khartoum and Their Future Plans}

The youth indicated the life in Khartoum is not easy. These youth are very vulnerable in the city because they have left their parents and their villages where they would have been afforded with a fall back options in times of crisis, while in the city there are no formal institutions that provide support for unemployed youth.

\section{Conclusions and Recommendation}

In conclusion, young migrants are more vulnerable when, in combination with their age and stage of life, they face isolation, exclusion, discrimination, and insecurity. Moreover, in the migration process young people can lose their social networks and may also be without parents or family members to provide guidance and care.

It is concluded that the lack of integration of the youth with Khartoum State community because they did not have time and their livelihood style isolated them from community.

The study recommended, A Social protection of youth, Protecting youth from health and behavioral risks: Young people are, due to their age and lack of experience, vulnerable to behavioral risks such as delinquency, substance abuse, involvement in gangs, unprotected and multiple sexual relations, etc. Because they 
are away from their parents and from their village which has been the source of moral guidance and support, these youth need institutional support and guidance. The following activities can help to protect youth:

- Accessible youth centers where different services including guidance can be provided.

- Provide regular workshops, orientation and entertainments to create and promote awareness.

\section{Conflicts of Interest}

The authors declare no conflicts of interest regarding the publication of this paper.

\section{References}

[1] Yaqub, S. (2009) Child Migrants with and without Parents: Census-Based Estimates of Scale and Characteristics in Argentina, Chile and South Africa. Discussion Paper, IWP-2009-02. UNICEF Innocenti Research Centre, Florence, Italy.

[2] Bello, A. (2008) Development as a Historical Process in the Nuba Mountains Region in Sudan. Journal of Dirasat Ifriqiyya, 39, 1-12. 